\title{
SOME UNIQUE ETHNOPHARMACEUTICAL CLAIMS FROM BHULESHWAR AREA PUNE DISTRICT (M.S.) INDIA Samudra $\mathbf{S} \mathbf{M}$ *
}

Department of Botany, K.G. Kataria College Daund, Pune- 413801.

\begin{abstract}
:
Present communication focuses on some of the less commonly used ethno pharmaceutical home remedies against various human and pet animals diseases and disorders cures in Bhuleshwar area of Daund tahsil from Pune district (M.S.) India. In all total 15 plant species belonging to 15 genera from 13 angiosperm families have been documented. Of these, uses of --plant species found unknown or less known to India.
\end{abstract}

KEYWORDS: Ethnopharmaceutical, traditional herbal/medicine men, Bhuleshwar.

\section{INTRODUCTION:}

Today chemists could able to synthesis many other drug, but many other drugs still come from the plants. At present, it is estimate and that there are about 30,000 plants having medicinal value. In India over 7000 plants are known and used for medicinal purpose (Holly and Williams, 1996). Most of the modern synthetic drugs have attacked the targets blindly and affected badly on several related metabolic processes. On other hand, the ethno pharmaceutical herbal medicines probably have more accuracy and effectiveness in working, more specific in action and have no side effects. Further same drugs are affordable, eco-friendly and easily available in local markets. During the present investigation, 15 plant species belonging to 15 genera from 13 angiosperm families have been documented from Bhuleshwar area.

The study area-

The study area under the investigation study is an ideal place famous for its Hindu temple of Shiva and diverse ethnoflora of ethnopharmaceutical significance and situated around 45 kilometer from pune and 10 kilometer from Pune Solapur highway from Yawat in Daund tahsil .It covers an area of 3.5 $\mathrm{km} 2$ and lies at an altitude of 78 meters from MSL (Mean Sea Level) and is located in between $18^{\circ} .47^{\prime} \mathrm{N}-74.6^{\circ} \mathrm{E}$ latitude and longitude. The area under the study is occupied by forest area of $1.75 \mathrm{~km} 2$ with $12.5 \%$ mixed-deciduous vegetation with an average rainfall of about 108 $\mathrm{mm}$ and temperature range of $26^{\circ} \mathrm{C}$ to $47.8^{\circ} \mathrm{C}$. So far the study concerned, area under the study is unexplored up to today.

\section{MATERIAL AND METHODS:}

Frequent field visits were arranged in the study area season wise during the period from premonsoon of 201 5to post-monsoon of 2016 to collect the data on ethno pharmaceutical uses of the native wild ethno-flora with the help of the local inhabitants. The plant material of ethno pharmaceutical significance was collected in coordination with the local informants and the information about the local names of the plant species along with uses, was cross checked and confirmed through verbal interviews in an informal ways with the help of local traditional healers and the local medicine men. . Collected plant specimens were identified by the Flora of Bombay Presidency by Cooke (1958). The herbarium sheets were deposited in the Botany Dept of the college for future study.

\section{RESULTS \& DISCUSSION:}

The present paper focuses on ethno pharmaceutical uses of 15 plant species belonging to 13 angiosperm families used for curing of certain diseases and disorders in Bhuleshwar areas of Daund tahsil from Pune district (M.S.) India. Most of the formulations are orally administered either in the form of extract, juice, infusion or decoction.

\section{CONCLUSION:}

The study area denotes the wisdom of the local traditional healers and medicine men along with native knowledgeable informants in regards to traditional ethno pharmaceutical knowledge. The study focuses on immense scope and wide potential for researches in the area. In order to document, conserve and evaluate the information, collective efforts are needed from the ethno-botanists and ethno-pharmaceutical scientists. It's our prime duty to conserve, document and spread this indigenous traditional knowledge through various media, before its disappearance. Due to various types of human interference and deforestation, vast amount of ethno-flora is under the threat of extinction. To preserve it, urgent need of collaborative work regarding urgent protection and preservation of the native wild ethno flora by the villagers, semigovernment and government authorities is essential.

Rural, tribal and non-tribal and native human populace participation can be initiated by giving 
incentives to local inhabitants and creating general awareness among them in regards to usefulness of the native ethno-flora. The central and the state government authorities should encourage the experts in exploration of the hidden ethno botanical wisdom which will help us in elevating the export of herbal medicines and increasing herbal trade with the major countries around the world. This will also improve the health and quality of life on the earth plant.

\begin{tabular}{|c|c|c|c|c|c|}
\hline $\begin{array}{l}\text { Sr. } \\
\text { No }\end{array}$ & $\begin{array}{l}\text { Botanical Name } 8 \\
\text { Family }\end{array}$ & $\begin{array}{l}\text { Local } \\
\text { Name }\end{array}$ & Habit & $\begin{array}{l}\text { Plant } \\
\text { Part }\end{array}$ & Herbal formulations for treatment \\
\hline 1. & $\begin{array}{l}\text { Aegle marmelos (L.) } \\
\text { Corr. ( Rutaceae ) }\end{array}$ & Bael & Tree & Fruit & $\begin{array}{l}\text { Fruit pulp is boiled in cupful sheep milk with } \\
\text { little quantity of jiggery and consumed twice a } \\
\text { day up to } 8-10 \text { days to cure amoebic dysentery. }\end{array}$ \\
\hline 2. & $\begin{array}{l}\text { Asparagus acemosus } \\
\text { wild. ( Liliaceae ) }\end{array}$ & Shatmuli & Herb & Root & $\begin{array}{l}\text { An extract from a tola (aprox. } 10 \mathrm{gm} \text { ) of fresh } \\
\text { root-tubers is boiled with goat's milk for } 10-20 \\
\text { seconds and above formulation is given with } 1- \\
2 \text { tsp honey to improve lactation ability and } \\
\text { duration in newly nursing mothers. }\end{array}$ \\
\hline 3. & $\begin{array}{l}\text { Boerrhavia diffusa } \mathrm{L} . \\
\text { ( Nyctaginaceae ) }\end{array}$ & Ghomati & Herb & $\begin{array}{l}\text { Leave } \\
\mathrm{s}\end{array}$ & $\begin{array}{l}\text { A cupful decoction from young leaves is mixed } \\
\text { with a pinch of cane sugar and above } \\
\text { formulation preparation is consumed twice a } \\
\text { day up 8-10 days to cure jaundice. }\end{array}$ \\
\hline 4. & $\begin{array}{l}\text { Jatropha curcas L. } \\
\text { ( Euphorbiaceae ) }\end{array}$ & $\begin{array}{l}\text { Parshi } \\
\text { erand }\end{array}$ & Shrub & Seed & $\begin{array}{l}\text { An infusion from fresh seeds is mixed with } \\
\text { equal amount of jiggery and above formulation } \\
\text { is given orally with } 1-2 \text { tsp of honey twice a day } \\
\text { up to } 5-6 \text { days to remove tapeworms. }\end{array}$ \\
\hline 5. & $\begin{array}{l}\text { Ficus microcarpa } \\
\text { Linn. f } \\
\text { ( Moraceae ) }\end{array}$ & Nandruk & Tree & Roots & $\begin{array}{l}\text { Decoction of fresh and young aerial roots made } \\
\text { in sheep's milk is given orally to the patient } \\
\text { once a day in the early morning up to } 12-15 \\
\text { days cure typhoid. }\end{array}$ \\
\hline 6. & $\begin{array}{l}\text { Phyllanthus niruri } \\
\text { Hook. } \\
\text { ( Euphorbiaceae ) }\end{array}$ & $\begin{array}{l}\text { Ran } \\
\text { jondhala }\end{array}$ & Herb & $\begin{array}{l}\text { Leave } \\
\mathrm{s}\end{array}$ & $\begin{array}{l}\text { Chatak (aprox.50gm) fresh and healthy leaves } \\
\text { and tender shoots are boiled in } 2-3 \text { cups of } \\
\text { goat's milk and the resultant formulation is } \\
\text { given orally to the patient once a day up to } 10- \\
12 \text { days with } 1-2 \text { tsp of honey to cure chronic } \\
\text { stomach ache. }\end{array}$ \\
\hline 7. & $\begin{array}{l}\text { Hemidesmus indicus } \\
\text { (L.) Schult ( } \\
\text { Asclepiadaceae ) }\end{array}$ & Kavilvel & Herb & Stem & $\begin{array}{l}1.0 \text { to } 1.5 \mathrm{~cm} \text { long stem pieces immersed in } \\
\text { haladi (Curcuma domestica) powder are stung } \\
\text { in a leather strip and above garland is tied } \\
\text { around the neck of pet cow and buffaloes up to } \\
\text { for } 11-15 \text { days to cure haemorrhage. }\end{array}$ \\
\hline 8. & $\begin{array}{l}\text { Luffa acutangula (L.) } \\
\text { Roxb } \\
\text { ( Cucurbitaceae ) }\end{array}$ & Dodka & $\begin{array}{l}\text { Climb } \\
\text { er }\end{array}$ & Fruit & $\begin{array}{l}\text { 1-2 tsp powder from shade dried fruits is boiled } \\
\text { in 1-2 glasses of goat's milk and same } \\
\text { formulation is given internally twice a day up to } \\
8-12 \text { days to cure hepatitis. }\end{array}$ \\
\hline 9. & $\begin{array}{l}\text { Trichosanthes } \\
\text { bicuspidate Lour. ( } \\
\text { Cucurbitaceae ) }\end{array}$ & Padwal & $\begin{array}{l}\text { Climb } \\
\text { er }\end{array}$ & Fruit & $\begin{array}{l}2-3 \text { tsp of juice from mature fruits boiled in a } \\
\text { glassful of cow's urine for } 10-15 \text { seconds in } \\
\text { iron pan and same preparation is dropped into } \\
\text { eyes twice a day up to } 18-21 \text { days to to relieve } \\
\text { inflammation. }\end{array}$ \\
\hline 10. & $\begin{array}{l}\text { Ocimum sanctum L. } \\
\text { ( Lamiaceae ) }\end{array}$ & $\begin{array}{l}\text { Krishna } \\
\text { tulshi }\end{array}$ & Herb & $\begin{array}{l}\text { Whole } \\
\text { plant }\end{array}$ & $\begin{array}{l}\text { Women from Hindu community in this area are } \\
\text { administered to make } 9-12 \text { rotations around } \\
\text { the plant garden in early morning after bath to } \\
\text { maintain physical and mental health. }\end{array}$ \\
\hline 11. & $\begin{array}{l}\text { Cryptolepis } \\
\text { buchanani Roem \& } \\
\text { Schult. } \\
\text { ( Periplocaceae ) }\end{array}$ & $\begin{array}{l}\text { Krishna } \\
\text { sariva }\end{array}$ & Herb & Stem & $\begin{array}{l}\text { One to two inches long fresh stem pieces } \\
\text { stitched in a thin leathery thread are tied } \\
\text { around the neck for patient up to } 15-18 \text { days to } \\
\text { cure jaundice. }\end{array}$ \\
\hline 12. & $\begin{array}{l}\text { Alstonia scholaris (L.) } \\
\text { R.Br. } \\
\text { ( Apocynaceae ) }\end{array}$ & $\begin{array}{l}\text { Saptapar } \\
\text { ni }\end{array}$ & Tree & $\begin{array}{l}\text { Exud } \\
\text { ates }\end{array}$ & $\begin{array}{l}\text { Two to three tsp fresh latex of the plant is } \\
\text { boiled in a half cup of pig ghee and above } \\
\text { formulation dropped twice or thrice day until } \\
\text { cure. }\end{array}$ \\
\hline 13. & $\begin{array}{l}\text { Tridax procumbens } L . \\
\text { (Asteraceae) }\end{array}$ & kutkuti & Herb & Leaf & $\begin{array}{l}\text { A handful fresh leaves with a pinch of haldi } \\
\text { (Curcuma domestica) powder are crushed in }\end{array}$ \\
\hline
\end{tabular}




\begin{tabular}{|c|c|c|c|c|c|}
\hline & & & & & $\begin{array}{l}\text { half cup of cow urine and poultice is applied 2- } \\
3 \text { times a day for } 10 \text { days to heal wounds. }\end{array}$ \\
\hline 14. & $\begin{array}{l}\text { Triumfetta } \\
\text { rotundifolia Jacg. ( } \\
\text { Tiliaceae ) }\end{array}$ & Zinjurdi & Herb & Leaf & $\begin{array}{l}\text { Fine paste from aatpav fresh and healthy } \\
\text { leaves is boiled in safflower (Cathamum } \\
\text { tinctorius ) seed oil with a pinch of common } \\
\text { salt and above formulation is topically two to } \\
\text { three times a day until total heal. }\end{array}$ \\
\hline 15. & $\begin{array}{l}\text { Celastrus } \\
\text { paniculatus Willd. ( } \\
\text { Celastraceae ) }\end{array}$ & $\begin{array}{l}\text { Malkango } \\
\text { ni }\end{array}$ & Shrub & Leaf & $\begin{array}{l}\text { The fresh leaves are crushed with } 4-6 \text { lasun } \\
\text { (Allium sativum) cloves in half cup of coconut } \\
\text { oil and the extract is applied topically twice a } \\
\text { day up to 5-6 days. }\end{array}$ \\
\hline
\end{tabular}

\section{REFERENCES:}

Almeida, MR. Flora of Maharashtra. Blatter Herbarium, St. Xavier's College, Mumbai, 1996; 369.

Anmol Kumar. 1993. Melghat - Forest of Melghat, In Two Decades of Project Tiger, Melghat, (1973-1993), Post, present and future. Papers and Proceeding Ed. Pp. 111-114. Department of Forests, Maharashtra State, Pune.

Asolkar, LV, Kakkar KK and Chakra OJ Second supplement to glossary of Indian Medicinal plants with Active principles. Part I (AK), (1965-81). Publications \& Information Directorate, CSIR, New Delhi, 1992; 358.

Bawdekar, P. 2001. 151 Prakalpa Rupresha, Mitcon consultancy services, Pune. India.

Chopra, RN, Nayar SN, Chopra, IC Glossary of Indian Medicinal Plants, C.S.I.R. New

Delhi, 1956; 36.

Chopra, R. N., D. Chopra \& B. S. Varma. 1969. Supplement to Glossary of Indian Medicinal Plants. Publications \& Information Directorate, CSIR, New Delhi.

Chopra, R. N., I. C. Chopra. \& K. L. Kapur. 1958. (Sec.Edu.) Indigenous drugs of India. U.N. Dhur \& Sons private limited 15, Bankim Chatterjee Street, Calcutta-12, Pp. 134-423.

Cooke, T. The Flora of the Presidency of Bombay, Vols 1 \& II, Repr. edr, Government of India, 1958; 357

Daniel, M. 1991. Methods in Plant Chemistry and Economic Botany. Kalyani publishers, New Delhi.p.32-37.

Janaki Ammal, EK. Introduction to the subsistence economy of India. In: Man's role in changing face of the earth (ed. William L.T.Jr),
University of Chicago Press, Chicago, 1956; 32435.

Jain, SK Ethnobotany: Its scope and study in India. J. Museum Bull., 1967; 2(I): 39-43.

Jain, SK. Methods and approaches in Ethnobotany, Society of Ethnobotanists, C.D.R.I., Lucknow, 1989.

Jain, SK and Mudgal VA. A Handbook of Ethnobotany, Bishen Singh Mahendra Pal Singh, Dehradun, 1999; 58-63.

Jain, SK. Methods and approaches in Ethnobotany, Society of Ethnobotanists, Luknow, 1989; 127-31.

Khan, MA and Chowdhury SK Traditional medicine in Bangladesh, 2002; 275-278 in Traditional Medicine in Asia. (edr. Chaudhury RR and Rafei UM) World Health Organization, SEARO Regional Publications No.30, New Delhi.

Mehrotra, S and Mehrotra BN Role of traditional and folklore herbals in the development of new drugs. J. Ethnobot, 2005; 17: 104-11.

Schulte, RE. The role of Ethnobotanists in search for new medicinal plants. J. Lloydia, 1962; 25(4): 257-66.

Singh NP and Kartikeyan $\mathbf{S}$ Flora of Maharashtra State, Bot. Surv. India, Calcutta, 2002; II.

Singh, NP, Lakshinarshimhan $\mathrm{P}$ and Prassanna PV Flora of Maharashtra State Vol. II., Bot. Surv. India, Calcutta, India, 2001.

Pradhan, SG and Singh NP. Flora of Ahmednagar District. (M.S.), Bishen Singh Mahendra Pal Singh. Dehradun, 1999; 339. 